\title{
Micropropagation of the Endangered Shrub Pondberry (Lindera melissifolia [Walt.] Blume)
}

\author{
Tracy S. Hawkins ${ }^{1}$, Nathan M. Schiff, Emile S. Gardiner, \\ Theodor Leininger, Margaret S. Devall, Dan Wilson, and \\ Paul Hamel \\ U.S. Department of Agriculture Forest Service, Center for Bottomland \\ Hardwoods Research, P.O. Box 227, Stoneville, MS 38776
}

Deborah D. McCown

Knight Hollow Nursery Inc., 7911 Forsythia Court, Middleton, WI 53562

\section{Kristina Connor}

U.S. Department of Agriculture Forest Service, 520 Devall Drive, Auburn, AL 36849

Additional index words. auxin, axillary shoot, Lauraceae, Lindera melissifolia, proliferation, zeatin

\begin{abstract}
A micropropagation protocol using shoot cultures is described for Lindera melissifolia, a federally listed endangered shrub endemic to the southeastern United States. Stock plants were harvested from native $L$. melissifolia populations growing in the lower Mississippi Alluvial Valley. In vitro proliferation was on woody plant medium supplemented with 1 MM zeatin. After 6 weeks, zeatin level was increased to $5 \mu \mathrm{M}$. Treatment of micropropagated shoots with a liquid auxin ( 2 indole-3-butyric acid : 1 1naphthalenacetic acid) resulted in a low mean rooting percentage $(\leq 44 \%)$ compared with rooting in the absence of auxins and on a pure peat medium ex vitro, which increased rooting to $\geq \mathbf{8 0} \%$. Time to rooting was 8 weeks. Plants were acclimatized for 2 weeks, then potted in a 2 peat : 1 perlite medium supplemented with superphosphate, $10 \mathrm{~N}-10 \mathrm{P}-10 \mathrm{~K}$, and Milorganite. Micropropagated $L$. melissifolia stecklings have been successfully outplanted in both controlled and field studies at the Center for Bottomland Hardwoods Research (Stoneville, Miss.).
\end{abstract}

Micropropagation has proven to be useful in research and conservation of endangered plant species. In efforts to sustain naturally occurring populations, micropropagation has been used to maintain and restore genetic diversity (Godt et al., 1997; Hammatt and Evans, 1985; Machon et al., 2001) and supplement populations in their native habitat (Anand and Rao, 2000; Jamison and Renfroe, 1998). Furthermore, micropropagation provides a means of mass producing plants, thereby relieving harvesting pressure on those species of economic importance (Negash, 2002; Rai, 2002; Rosas et al.,

Received for publication 10 Aug. 2006. Accepted for publication 12 Oct. 2006.

We thank Ben Ware, Stephanie Skojac, and Bryce Burke for their assistance during field collection; U.S. Fish and Wildlife Service for collection permits; the U.S. Army Corps of Engineers for underwriting some of the cost of this research, and Craig Echt and Brian Lockhart for critical reviews of an earlier draft of this manuscript.

Mention of a trademark, proprietary product, or vendor does not constitute a guarantee or warranty of the product by the U.S. Department of Agriculture and does not imply its approval to the exclusion of other products or vendors that also may be suitable.

${ }^{1}$ To whom reprint requests should be addressed; e-mail tracyhawkins@fs.fed.us
2001; Rubluo et al., 1993). In the United States, federal policy restricts reintroduction of propagated plants as a recovery strategy unless all other methods to improve a listed species status have failed, or have proved to be ineffective (U.S. Fish and Wildlife Service, 2000). However, federal policy does allow propagation of endangered plant species for purposes of scientific research.

In 2002, the Center for Bottomland Hardwoods Research (CBHR) began conducting extensive, multidisciplinary research on Lindera melissifolia, a federally endangered shrub (U.S. Fish and Wildlife Service, 1986) endemic to the southeastern United States. Of special concern were L. melissifolia populations growing in periodically flooded bottomland forests in the Mississippi Delta of the Lower Mississippi Alluvial Valley (LMAV). The LMAV has been described as one of the most endangered ecosystems in the United States (Noss et al., 1995), primarily affected by agriculture and changes in hydrologic cycles from flood control projects (Stanturf et al., 2000). In light of the potential for future anthropogenic disturbance in this physiographic region, and in keeping with the pondberry recovery plan (U.S. Fish and Wildlife Service, 1993), a need exists for an understanding of life history attributes of L. melissifolia and development of management practices that will ensure the sustainability of native populations.

In order for CBHR to carry out pondberry research, it was necessary that 1) acquisition of large quantities of plants did not create a severe harvesting impact on naturally occurring pondberry populations, 2) plants used in the research process represented a reasonable cross-section of genotypes from the Mississippi Delta, and 3) upon initiation of some studies, plants be of the same physiological age and of reasonably uniform size. It was decided that micropropagation would be the best alternative for satisfying these criteria. Therefore, the objective of this initial investigation was to establish a protocol for micropropagation of L. melissifolia.

\section{The Species}

Lindera melissifolia (common name: pondberry) is an aromatic shrub classified in Lauraceae. The species is dioecious, and anthesis precedes leafing out. Reproduction is both sexual (seeds) and asexual (rhizomes). Although the natural range for L. melissifolia extends from the LMAV (specifically, Arkansas, Mississippi, and Missouri) east to North and South Carolina, relatively small, disjunct populations are sparsely distributed within this range. These populations often are composed of several, single-sex colonies characterized by numerous, upright stems, largely the result of ramification. Populations tend to be male biased, with male-to-female colony ratios ranging from 5:1 to $19: 1$ (Hawkins, unpublished data).

\section{Materials and Methods}

Twenty-six locations for stock plant collection were randomly chosen from a list of 48 pondberry colonies previously identified and mapped by Gulf South Research Corporation, an independent environmental consulting firm. To ensure that stock plants represented an adequate cross-section of genotypes growing in the Mississippi Delta, the distance between collection sites was no less than $3 \mathrm{~km}$, and the minimum distance between stems collected within a site was no less than $16 \mathrm{~m}$. Leafless stems with roots were harvested in Mar. 2002. Plants were labeled with identification numbers in the field, transported to the laboratory, packaged, and shipped overnight to Knight Hollow Nursery, in Middleton, Wisc.

Bareroot stock plants were potted in a 2 peat : 1 perlite (by volume) medium and placed in a climate-controlled greenhouse to force growth. Explants (vegetative shoots) were harvested from stock plants in May and June 2002. Explants were sterilized for 15 min in a $10 \%$ solution of sodium hypochlorite mixed with a few drops of commercial dishwashing liquid, then rinsed twice in sterile distilled water. Sterilized explants were placed on woody plant medium (WPM) (Lloyd and McCown, 1980) supplemented with $1 \mu \mathrm{M}$ zeatin, and with a mixture of agar 


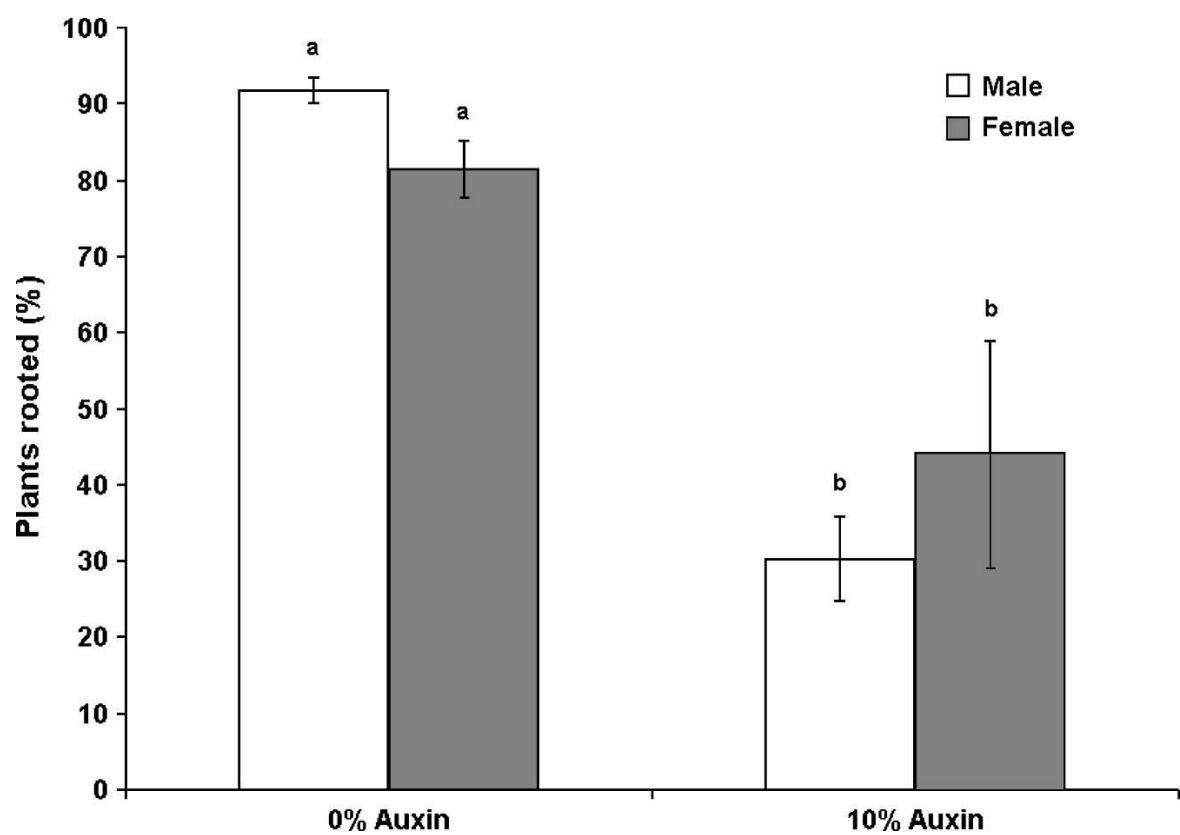

Fig. 1. Comparison of ex vitro rooting percentages for micropropagated shoots of male and female Lindera melissifolia plants treated with $0 \%$ auxin and $10 \%$ auxin ( 2 indole-3-butyric acid : 11 -naphthalenacetic acid) solutions. Within treatments, plant genders with different lowercase letters are significantly different $(P<0.05$, analysis of variance). Among treatments, rooting percentages with different lowercase letters are significantly different $(P=0.05$, protected LSD $)$.

(4 $\left.\mathrm{g} \cdot \mathrm{L}^{-1}\right)$ and Gelright $\left(1.4 \mathrm{~g} \cdot \mathrm{L}^{-1}\right)$ added as gelling agents. Explants were maintained at $28{ }^{\circ} \mathrm{C}$ under 24 -h cool-white fluorescent lights suspended $\approx 8.0 \mathrm{~cm}$ above the plant trays. After 6 weeks, the zeatin level was increased to $5 \mu \mathrm{M}$. Thereafter, L. melissifolia microshoots were subcultured on a 6-week cycle by shoot culture on WPM supplemented with $5 \mu \mathrm{M}$ zeatin.

In Oct. 2002, micropropagated shoots $(\mathrm{N}=215)$ were dipped for $5 \mathrm{~s}$ in a $10 \%$ solution of Dip 'n Grow, a commercially available liquid auxin rooting hormone consisting of $1 \%$ indole-3-butyric acid and 0.5\% 1-naphthalenacetic acid. Treated shoots were placed in $25 \times 50-\mathrm{cm}$ flats filled with a commercial peat-perlite propagation medium (ProMix BX; Grace-Sierra, Premier Horticulture, Red Hill, Pa.), and watered with a prophylactic fungicide solution of metalaxyl (Subdue; Syngenta Crop Protection, Greensboro, N.C.) and thiophanate methyl (Cleary's 3336; Cleary Chemical Corp., Dayton, N.J.). Flats were covered with clear plastic domes and maintained at $28{ }^{\circ} \mathrm{C}$ under $24-\mathrm{h}$ fluorescent light for 3 months. Results of this rooting protocol suggested that additional testing of rooting methods was needed. Subsequently, micropropagated shoots were given one of six liquid auxin rooting treatments at concentrations of $0 \%, 20 \%, 40 \%$, $60 \%, 80 \%$, or $100 \%(\mathrm{v} / \mathrm{v})$. Treated microshoots were placed in flats containing a $100 \%$ peat medium. Temperature and light treatments were the same as those used in the initial rooting trial. After 4 weeks, flats were subirrigated with a $0.4 \%$ solution of Miracid. At week 8 , plants were acclimatized to ambient humidity for $\approx 2$ weeks by venting the plastic domes covering the flats. After acclimatization, plants were potted in a 2 peat : 1 perlite medium supplemented with superphosphate $\left(467 \mathrm{~g} \cdot \mathrm{m}^{-3}\right)$ and $10 \mathrm{~N}-10 \mathrm{P}-10 \mathrm{~K}\left(1133 \mathrm{~g} \cdot \mathrm{m}^{-3}\right)$, and Milorganite $\left(2267 \mathrm{~g} \cdot \mathrm{m}^{-3}\right)$.

The square root of rooting percentages were arcsine transformed before they were analyzed and were back-transformed for presentation. Mean rooting percentages were compared by one-way analysis of variance, and the protected LSD test $(P=0.05)$ was used as the multiple comparison procedure (SAS system for Windows, version V8; SAS Institute, Cary, N.C.).

\section{Results and Discussion}

Selection of a micropropagation method for L. melissifolia was, to a certain degree, influenced by research demands. First, this process needed to produce stecklings (rooted, juvenile plants ready for outplanting) genetically identical to their respective stock plant. Maintenance of genetic integrity would ensure morphological and physiological similarity to L. melissifolia populations from which stock plants were harvested. Additionally, it was desirable that stecklings be relatively uniform in physiological age. Potential methods of somatic regeneration are meristem tip culture, adventitious shoot induction, and axillary shoot proliferation. The latter method was used because it yields a high level of genetic stability (Lloyd and McCown, 1980) and, during proliferation, stimulation of areas of the axillary buds in contact with the medium are synchronized; therefore, the physiological age of propagules is uniform (McCown, 1985).

Although less economical than some synthetic cytokinins such as $2 \mathrm{iP}[\mathrm{N} 6-(\Delta 2-$ isopentenyl)-adenine] and BAP (6-benzylaminopurine), an endogenous hormone, zeatin [(2E) 2-methyl-4-(1H-purin-6ylamino)-2-buten-lol] was used during the proliferation phase because it has been observed to be less toxic to some woody plant species (Eccher and Noe, 1989; McCown and Lloyd, 1982; Tetsumura and Yamashita, 2004). Supplementing WPM with zeatin yielded a minimum twofold proliferation rate. Zeatin did cause slight basal callusing, which was either pinched off at rooting or ignored, depending on size.

Stabilization of L. melissifolia shoot cultures was complete after $\approx 10$ rounds of subculturing. Also referred to as rejuvenation, a stabilized micropropagule is characterized by rapid, uniform growth with smaller stems and leaves, typical of juvenile growth of the parent plant. Time to stabilization for L. melissifolia was fairly rapid relative to some woody plants with episodic growth, such as species of Fagus and Juglans (McCown and McCown, 1987).

The initial ex vitro rooting treatment using a $10 \%$ auxin solution yielded somewhat low mean $( \pm \mathrm{SE})$ rooting percentages of $30 \pm 5 \%$ and $44 \pm 15 \%$ for male and female plants respectively (Fig. 1). In the second rooting trial, results of treatments along a gradient $(0 \%$ to $100 \%)$ of auxin concentrations showed a decrease in rooting percentages with increase in auxin concentration. Analysis of data collected from the $0 \%$ auxin treatment and that of the initial rooting protocol ( $10 \%$ auxin treatment) showed that rooting percentages were significantly greater $(P<0.0001)$ in the absence of auxins, than in the initial $10 \%$ auxin treatment (Fig. 1). Rooting response within treatments and between plant gender was not significantly different (Fig. 1). Currently, ex vitro rooting in the absence of auxin treatment, and on a pure peat medium, yields a rooting percentage $\geq 80 \%$ for all $L$. melissifolia male and female genotypes, with the exception of four genotypes that continue to root at a maximum rate of $50 \%$.

With modest selection for cutting size and leaf development before the rooting phase, the protocol established for micropropagation of L. melissifolia is extremely successful. To date, more than 10,000 stecklings representing 20 different male and female genotypes have been produced and used for field and controlled studies at the Center for Bottomland Hardwoods Research.

\section{Literature Cited}

Anand, A. and C.S. Rao. 2000. A rapid in vitro propagation protocol for Piper barberi Gamble, a critically endangered plant. In Vitro Cell. Dev. Biol. 36:61-64.

Eccher, T. and N. Noe. 1989. Comparison between $2 \mathrm{iP}$ and zeatin in the micropropagation of highbush blueberry (Vaccinium corymbosum). Acta Hort. 241:185-190.

Godt, M.J.W., T. Race, and J.L. Hamrick. 1997. A population genetic analysis of Ziziphus celata, an endangered Florida shrub. J. Hered. 88:5355.

Hammatt, N. and P.K. Evans. 1985. The in vitro propagation of an endangered species: Centaurea 
junoniana Svent. (Compositae). J. Hort. Sci. 60:93-97.

Jamison, J.A. and M.H. Renfroe. 1998. Micropropagation of Betula uber (Ashe) Fernald. In Vitro Cell. Dev. Biol. 34:147-151.

Lloyd, G. and B. McCown. 1980. Commerciallyfeasible micropropagation of mountain laurel, Kalmia latifolia, by use of shoot-tip culture. Proc. Intl. Plant Prop. Soc. 30:421-427.

Machon, N., J.M. Guillon, G. Dobigny, S. Le Cadre, and J. Moret. 2001. Genetic variation in the horsetail Equisetum variegatum Schleich., an endangered species in the Parisian region. Biodivers. Conserv. 10:1543-1554.

McCown, B.H. 1985. From gene manipulation to forest establishment: Shoot cultures of woody plants can be a central tool. Tappi J. 68:116119.

McCown, B.H. and G.B. Lloyd. 1982. A survey of the response of Rhododendron to in vitro culture. Plant Cell Tissue Organ Cult. 2:77-85.

McCown, D.D. and B.H. McCown. 1987. North American hardwoods, p. 247-260. In: J.M. Bonga and D.J. Durzan (eds.). Cell and tissue culture in forestry. Martinus Nijhoff Publishing, Dordrecht, the Netherlands.

Negash, L. 2002. Successful vegetative propagation techniques for the threatened African pencil cedar (Juniperus procera Hoechst. ex Endl.). For. Ecol. Manage. 161:53-64.

Noss, R.F., E.T. Laroe, III, and J.M. Scott. 1995 Endangered ecosystems of the United States: A preliminary assessment of loss and degradation. U.S. Biol. Report 28. Nat. Biol. Serv., Washington, DC.

Rai, V.R. 2002. Rapid clonal propagation of Nothapodytes foetida (Wight) Sleumer: A threatened medicinal tree. In Vitro Cell. Dev. Biol. 38:317-351.

Rosas, M.M., M.A. Monroy de la Rosa, K.M. Goldammer, and V.M. Chavez Avila. 2001. Micropropagation of Turbinicarpus laui Glass et Foster, an endemic and endangered species. In Vitro Cell. Dev. Biol. 37:400-404

Rubluo, A., V. Chavez, A.P. Martinez, and O. Martinez-Vazquez. 1993. Strategies for the recovery of endangered orchids and cacti through in-vitro culture. Biol. Conserv. 63:163-169.

Stanturf, J.A., E.S. Gardiner, P.B. Hamel, M.S Devall, T.D. Leininger, and M.E. Warren, Jr. 2000. Restoring bottomland hardwood ecosystems in the lower Mississippi Alluvial Valley. J. For. 98:10-16.

Tetsumura, T. and K. Yamashita. 2004. Micropropagation of Japanese chestnut (Castanea crenata Sieb. et Zucc.) seedlings. HortScience 37:1684-1687.

U.S. Fish and Wildlife Service. 1986. Endangered and threatened wildlife and plants; Determination of endangered status for Lindera melissifolia. Federal Register 51:27495-27500.

U.S. Fish and Wildlife Service. 1993. Recovery plan for pondberry (Lindera melissifolia [Walt.] Blume). U.S. Fish and Wildlife Service, Atlanta, Ga.

U.S. Fish and Wildlife Service. 2000. Policy regarding controlled propagation of species listed under the endangered species act. Federal Register 65:56916-56922. 